\title{
New taxa of Chrysomelidae (Coleoptera) collected in canopy trees of South Vietnam
}

\author{
Новые таксоны Chrysomelidae (Coleoptera), \\ собранные в кронах деревьев Южного Вьетнама
}

\author{
L.N. Medvedev \\ M.H. Медведев
}

Institute for Problems of Ecology and Evolution, Russian Academy of Sciences, Leninsky prospect 33, Moscow 119071 Russia. Институт проблем экологии и эволюции РАН, Ленинский проспект 33, Москва 119071, Россия.

KEY WORDS: Chrysomelidae, South Vietnam, canopy trees, new taxa.

КЛЮЧЕВЫЕ СЛОВА: Chrysomelidae, Южный Вьетнам, кроны деревьев, новые таксоны.

ABSTRACT. New genus (Eristana gen.n.) and 7 new species: Cryptocephalus lamdongi, Nodina polilovi, Chrysolampra purpurea, Colaspoides polilovi, Pyrrhalta nigrotibialis, Trichomimastra vietnamica, Erystana vietnamica spp.n. collected in canopy trees of South Vietnam are described.

РЕЗЮМЕ. ОПисываются новый род (Eristana gen.n.) и 7 новых видов: Cryptocephalus lamdongi, Nodina polilovi, Chrysolampra purpurea, Colaspoides polilovi, Pyrrhalta nigrotibialis, Trichomimastra vietnamica, Erystana vietnamica spp.n., собранных в кронах деревьев Южного Вьетнама.

\section{Introduction}

I have had a good opportunity to study very interesting and unusual material from canopy trees of South Vietnam. This material was collected with using traps with fixed liquid, which were placed in canopy of different trees at altitude from 1 to 30 meters. More than 70 specimens of leaf beetles were collected, representing 40 species: Cryptocephalinae - 1, Eumolpinae 18, Galerucinae - 15, Alticinae - 5, Cassidinae - 1, among them 1 new genus and 7 new species. It seems that canopy fauna of Chrysomelidae is very specific and differs sharply from usual "terrestrial" fauna. All types are deposited in author's collection.

\section{Taxonomical part}

\section{Cryptocephalus lamdongi L.N. Medvedev, sp.n.} Fig. 1.

MATERIAL. Holotype, $0^{x}$ - South Vietnam, Lam Dong Prov., National Park Bi Dup-Nui Ba, 10.V.2009, trap in crown of unknown tree, $\mathrm{h}=5 \mathrm{~m}$, leg. A. Polilov (LM).

DESCRIPTION. Reddish fulvous with elytra more pale; labrum frons and vertex, antennae except basal segments, all margins of scutellum, narrow basal margin and humeral spot on elytra, base of pygidium and hind margins of $3^{\text {rd }}$ and $4^{\text {th }}$ abdominal sternites black.

Body cylindrical. Head finely punctuate, clypeus triangular, frons strongly narrowed between upper lobes of eye (shorter than the length of the $1^{\text {st }}$ antennal segment). Antennae long, reach apical slope of elytra, proportions of segments are as 12-5-9-11-15-16-16-16-15-15-18. Prothorax 1.5 times as wide as long, broadest at base strongly convex, with side margins not seen from above, surface impunctate. Scutellum cordiform, as long as wide, impunctate. Elytra 1.15 times as long as wide, slightly widened to behind, with regular rows of fine punctures and broad, flat interspaces. Pygidium flat, finely punctuate. Prosternum without collar. Aedeagus with triangular apex and preapical oblique groove on each side of underside (Fig. 1).

Length of body $4.4 \mathrm{~mm}$.

DIAGNOSIS. Resembles C. punctohumeralis Pic, 1920, described from South Vietnam, differs with smaller size, black vertex and antennae, black marks on pygidium and abdomen.

\section{Nodina polilovi L.N. Medvedev, sp.n.} Fig. 2.

MATERIAL. Holotype, $\sigma^{7}-$ South Vietnam, Dongnai Prov., National Park Cat Tien, Lagerstremia forest, trap on Tetramelis, $\mathrm{h}=1 \mathrm{~m}, 14-31 . \mathrm{IV} .2009$, leg. A. Polilov (LM).

DECRIPTION. Upperside metallic bronze, antennae, underside and legs blackish bronze.

Body short ovate, 1.35 times as long as wide. Clypeus very finely and densely punctuate, shallowly emarginated apically, frons almost impunctate, vertex and occiput with distinct punctures. Antennae reach humerus, with 6 thickened apical segments, proportions of segments are as 5-3-22-3-3-3-3-3-3-6. Prothorax 1.8 times as wide as long, broadest near base, narrowed anteriorly, with rounded anterior and distinct posterior angles, surface convex, shining, with moderately dense punctures, which are a little denser on sides; interspaces mostly comparable with diameter of punctures, flat. Segment 1 of fore and mid tarsi feebly widened. Scutellum nearly as broad as long, rounded-obtuse behind, punctuate. Elytra as long as wide, subparallel with broadly rounded apices, surface convex, without basal swelling, with 
regular rows of punctures distinct to apex, including sutural row, but became more feeble in apical third, interspaces rather broad and flat, outermost interspace broader, with a few punctures in basal part. Aedeagus - Fig. 2.

Length of body $1.9 \mathrm{~mm}$

DIAGNOSIS. Near N. clypeata Kimoto et Gressitt, 1982, but differs with other form and sculpture of clypeus and different form of aedeagus, having almost truncate apex

\section{Chrysolampra purpurea L.N. Medvedev, sp.n.} Fig. 8 .

MATERIAL. Holotype, + - South Vietnam, Dongnai Prov. National Park Cat Tien, Lagerstremia forest, trap on Tetramelis, $\mathrm{h}=20 \mathrm{~m}, 14 . \mathrm{IV} .2009$, leg. A. Legalov (LM). Paratypes: 1 - same label, 31.IV.2009, h of trap $=10 \mathrm{~m} ; 1$ ㅇ - same label and date, $\mathrm{h}$ of trap $=25 \mathrm{~m}$ (LM).

DESCRIPTION. Head and prothorax red cupreous, elytra purple to dark purple or violaceous, labrum, antennae and legs fulvous.

Body ovate. Clypeus triangle, finely and sparsely punctuate, frons punctuate on sides, with central impressed line, vertex impunctate, dull. Antennae thin, reach middle of elytra, proportions of segments are as 5-2-6-6-8-8-7-7-7-7-8. Prothorax twice as wide as long, broadest behind middle and distinctly narrowed anteriorly, surface with very sparse and fine punctures. Scutellum triangular with rounded apex and microscopical punctures. Elytra 1.3 times as long as wide, with dense and rather strong punctures, especially on sides, interspaces narrow, flat or moderately convex, apical slope of elytra with more or less regular rows of punctures. Last abdominal sternite with feebly incised hind margin. Propleurae shining, impunctate, with straight anterior margin. Anterior femora thickened, with large obtuse tooth, posterior femora with more small acute tooth. Spermatheca U-like (Fig. 8).

Length of body $4.6-5.0 \mathrm{~mm}$.

DIAGNOSIS. Near Ch. dentipes L.Medvedev, 2006, differs with much smaller size, entirely fulvous antennae and other colour of upperside.

\section{Colaspoides polilovi L.N. Medvedev, sp.n.} Fig. 9.

MATERIAL. Holotype, + - South Vietnam, Dongnai Prov. National Park Cat Tien, Lagerstremia forest, trap on Lagerstremia, $\mathrm{h}=1 \mathrm{~m}$, 5-14.IV.2009, leg. A. Polilov (LM).

DESCRIPTION. Reddish fulvous, elytra dark metallic blue. Body short ovate. Clypeus triangular, finely and sparsely punctuate, shallowly concave apically, not delimited from frons basally, frons and vertex practically impunctate, with feeble central groove. Antennae reach anterior third of elytra (3 apical segments absent), thin, proportions of segments are as 8-6-8-10-11-15-15-16, $8^{\text {th }}$ segment slightly thickened to apex, 4 times as long as wide at apex. Prothorax twice as wide as long, broadest at base, strongly narrowed anteriorly, feebly rounded on sides, with acute anterior and obtuse posterior angles, surface shining and impunctate. Scutellum triangular, impunctate. Elytra 1.5 times as long as wide, surface without basal convexity, with rather strong and moderately dense punctures, partly arranged on apical slope in rows, interspaces flat on whole surface. Pygidium with broad parallel-sided groove not ridged on bottom. Propleurae shining and impunctate. $5^{\text {th }}$ abdominal sternite slightly serrate on sides, arcuately concave on apex. All femora not toothed. Spermatheca U-like (Fig. 9).

Length of body $4.5 \mathrm{~mm}$.

DIAGNOSIS. Near C. laeta L.Medvedev, 2003 from Thailand and Malaysia, having same type of colour, but differs well in small and more ovate body and finely punctuate elytra, not having geminate rows and costate interspaces.

\section{Pyrrhalta nigrotibialis L.N. Medvedev, sp.n.} Fig. 3.

MATERIAL. Holotype, $\sigma^{\top}$ - South Vietnam, Dongnai Prov., National Park Cat Tien, Lagerstremia forest, trap on Sterculia, h=30 m, 31.IV-15.V.2009, leg. A. Polilov (LM).

DESCRIPTION. Fulvous, antennae black with segments 1 and 2 underside of segment 3 and bases of segments 10 and 11 fulvous, tibiae and tarsi black. Pubescence light.

Body rather strongly widened to behind. Clypeus transversely triangular, impunctate, frons and vertex roughly punctuate, frontal tubercles indistinct. Antennae reach anterior third of elytra, proportions of segments are as 12-5-11-119-10-10-10-10-9-13, preapical segments about twice as long as wide. Prothorax 2.2 times as wide as long, broadest just behind middle, side margins irregularly rounded, anterior angles slightly produced, posterior angles obtuse, surface densely punctuate, with feeble round impression on each side. Scutellum triangular, punctuate. Elytra 1.6 times as long as wide, surface finely and very densely punctuate, without any ridges and elevations along side margin. Aedeagus asymmetrical in apical half (Fig. 3).

Length of body $9.5 \mathrm{~mm}$

DIAGNOSIS. Very near to $P$. hanungus Samoderzhenkov, 1988, differs in colour of legs and form of aedeagus. In $P$. hanungus legs are entirely fulvous and aedeagus is practically symmetrical (Fig. 4).

\section{Trichomimastra vietnamica L.N. Medvedev, sp.n.} Figs 5-6.

MATERIAL. Holotype, $\sigma^{\top}$ - South Vietnam, Dongnai Prov., National Park Cat Tien, Lagerstremia forest, trap on Lagerstremia, $\mathrm{h}=15$ m, 14-31.IV.2009, leg. A. Polilov (LM). Paratypes: 19 - same locality and date, trap on Sterculia, $\mathrm{h}=20 \mathrm{~m}(\mathrm{LM}) ; 1 \mathrm{O}^{\mathrm{T}}$ - same locality and date, trap on Tetramelis, $\mathrm{h}=10 \mathrm{~m}$ (LM).

DESCRIPTION. Black, head, prothorax and scutellum fulvous, antennae fulvous with darckened apical segments or black with fulvous basal segments, legs fulvous with darkened tarsi, mid and hind tibiae (male) or with hind legs entirely black (female). Pubescence of elytra white.

Body narrow, elongate. Head impunctate, clypeus triangular with straight anterior margin and thin longitudinal ridge in middle, frontal tubercles triangular, transversely placed and delimited posteriorly with straight impressed line. Frons broad, about 3 times as wide as transverse diameter of eye. Antennae thin and long, reach apical slope of elytra, proportions of segments are as 14-6-12-14-12-12-11-11-10-1010 , preapical segments about 3 times as long as wide. Prothorax 1.6 times as wide as long, broadest just behind anterior margin, distinctly narrowed to base, side margins extremely feebly rounded, almost straight, fore and hind angles obtuse, with a pore bearing long bristle, surface impunctate, shining, feebly transversely flattened on each side of middle. Scutellum triangular, impunctate. Elytra $1.8-1.85$ as long as wide, parallel-sided, very finely rugose and indistinctly punctuate. Aedeagus thin and long, with apex curved downwards (Figs 5-6).

Length of male $3.3-3.4 \mathrm{~mm}$, of female $3.7 \mathrm{~mm}$.

DIAGNOSIS. Only one species, T. hirsuta Jacoby, 1892, was known from Vietnam. This species seems to be rather variable in colour, but never with combination of fulvous prothorax and black elytra and has aedeagus straight, with apex acute and not curved downwards. 


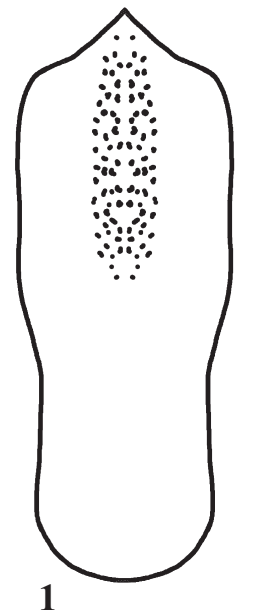

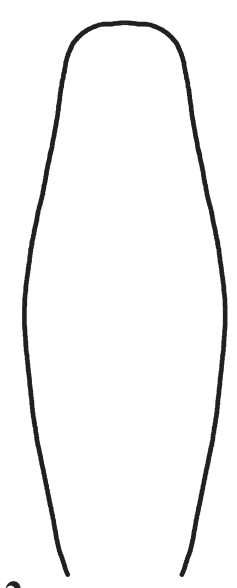

2

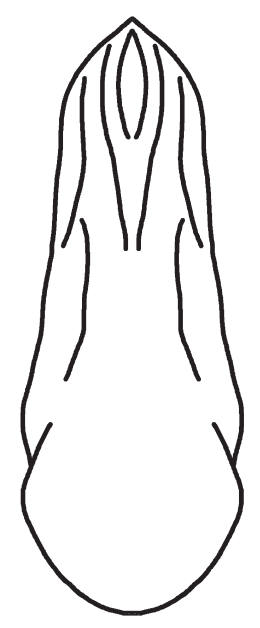

7

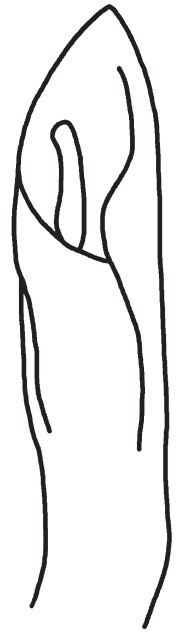

3

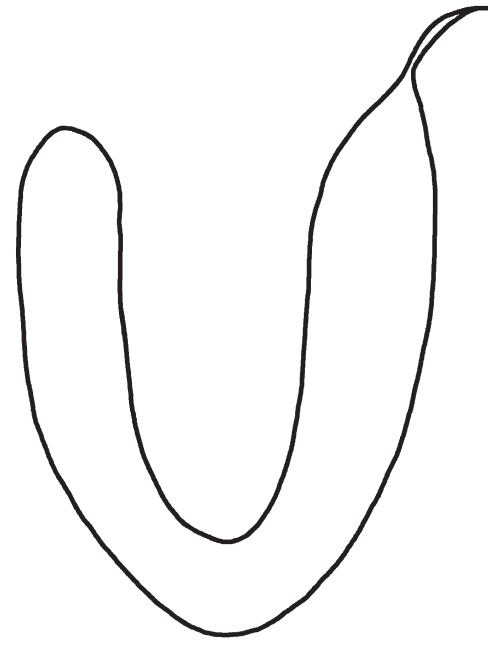

8

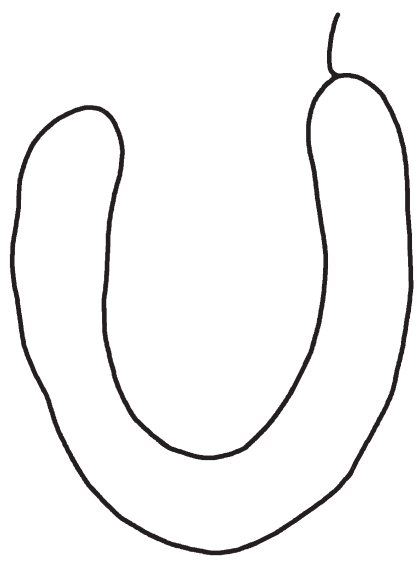

9

Figs 1-9. 1-6 - aedeagus: 1 - Cryptocephalus lamdongi sp.n.; 2 - Nodina polilovi sp.n.; 3 - Pyrrhalta nigrotibialis sp.n.; 4 - P. hanungus; 5-6 - Trichomimastra vietnamica sp.n.; 7 - Erystana vietnamica gen. et sp.n.; 8-9 - spermatheca: 8 - Chrysolampra purpurea sp.n.; 9 - Colaspoides polilovi sp.n. 1-2, 5, 7 - ventral; 3-4 - dorsal; 6 - lateral

Рис. 1-9. 1-6 - эдеагус: 1 - Cryptocephalus lamdongi sp.n.; 2 - Nodina polilovi sp.n.; 3 - Pyrrhalta nigrotibialis sp.n.; 4 - P. hanungi; 5-6 - Trichomimastra vietnamica sp.n.; 7 - Erystana vietnamica gen. et sp.n.; 8-9 - сперматека: 8 Chrysolampra purpurea sp.n.; 9 - Colaspoides polilovi sp.n. 1-2, 5, 7 - снизу; 3-4 - сверху; 6 - сбоку

Kimoto [1989] united with T. hirsuta 3 other species described from Vietnam by Weise and Laboissiere, but it needs further investigation, because proportions of basal antennal segments are rather different in these forms.

\section{Erystana L.N. Medvedev, gen.n.}

DESCRIPTION. Body short ovate, moderately convex. Frontal tubercles practically indistinct. Interantennal space broad. Vertex not excavated near eyes, which are not incised on inner margin. Prothorax transverse, without transverse basal impression, but with sharp longitudinal groove on each side of base. Elytra with lateral margin moderately widened, surface with regular rows of punctures, outermost interspace broad and convex. Epipleurae horizontal, longitudinally concave. Anterior coxal cavities closed. Hind femora thick. Tibiae not longitudinally channeled on dorsal segment bilobed.

DIAGNOSIS. A new genus has practically all characters of the genus Erystus Jacoby, 1885, but differs from it immediately with longitudinal grooves on each side of base. Same character of prothorax is known among Oriental genera only for Mantura Stephens, 1831 and partly Nisotra Baly, 1864, but a new genus differs from both with indistinct frontal tubercles, widened and thickened outermost interspace of elytra and longitudinally concave epipleurae. 


\section{Erystana vietnamica L.N. Medvedev, sp.n.} Fig. 7.

MATERIAL. Holotype, $\sigma^{7}-$ South Vietnam, Binh Phuoc Prov., Bu Gia Map National Park, trap on Hibiscus, h=25 m, 1322.IV.2009, leg. A. Polilov (LM). Paratypes: 9 ex. - with same label (LM). No doubt, Hibiscus is a foodplant of this species.

DESCRIPTION. Entirely fulvous. Head very finely punctuate, with smooth vertex, interantennal space as wide as antennal cavity. Antennae reach anterior fifth of elytra, proportions of segments are as 10-5-9-9-10-10-10-10-1010-13, preapical segments about 3 times as long as wide. Prothorax 1.9 times as wide as long, side margins feebly rounded, anterior angles produced exteriorly, with pore, surface finely and densely punctuate, basal longitudinal groove sharp and long, about $2 / 5$ of prothorax length. Scutellum small, triangular. Elytra 1.15-1.2 times as long as wide, scutellar row short, interspaces flat and finely punctuate, outermost interspace twice broader than preceding one, distinctly convex. Aedeagus - Fig. 7.
Length of body $4.0-4.4 \mathrm{~mm}$.

DIAGNOSIS. This species is very alike at Erystus mostovskii L.Medvedev, 2009, and differs mostly with generic character, also with entirely fulvous antennae. It is interesting that species of both genera feed on Hibiscus. Genus Erystus is still not found in Vietnam and only a year ago was registered in Indochina [Medvedev, 2009].

ACKNOWLEDGEMENTS. I am grateful to Dr. A. Polilov for possibility to study this interesting material.

\section{References}

Kimoto Sh. 1989. Chrysomelidae of Thailand, Cambodia, Laos and Vietnam. VI. Galerucinae // Esakia. Vol.27. P.1-241.

Medvedev L.N. 2009. Alticinae of Indochina. Moscow: KMK Scientific Press. 224 pp. 